\title{
Ensuring of Consumer Choice Ecologization on the Basis of Consumption Safety: International Experience for Ukraine
}

\author{
Kateryna Antoniuk ${ }^{*}$, Anatoly Mokiy ${ }^{2}$, Mariia Pikh $^{3}$, Lyudmila Bukharina ${ }^{4}$ and Dmytro Antoniuk ${ }^{4}$ \\ ${ }^{1}$ National University “Zaporizhzhia Politechnic”, Department of International Economic Relationships, 69063 Zaporizhzhia, Ukraine \\ ${ }^{2}$ SI "Institute of Regional Studies named after M.I. Dolishny NAS of Ukraine", Department of Regional Economic Policy, 79026 \\ Lviv, Ukraine \\ ${ }^{3}$ Lviv Professional College of Food Processing Industry of the National University of Food Technologies, 79000 Lviv, Ukraine \\ ${ }^{4}$ Zaporizhzhya National University, Department of Entrepreneurship, Management and Logistics, 69600 Zaporizhzia, Ukraine
}

\begin{abstract}
The article is devoted to the disclosure of the results of the study of threats to the environment, sustainable development and consumption safety that arise in the process of consumption. The problems of formation of the environment which promotes growth of ecological demand in Ukraine in comparison with other states are analyzed. Factors of internal, external and situational influence on consumer choice at each stage of consumption (awareness of needs, search for information, evaluation of alternatives, purchasing, use and utilization) are investigated. The main of them such as values, culture of consumption, marketing (promotion), level of development of institutional base (legislation, social norms) are established and their optimal level in conditions of uncertainty is proved. Conclusions are made on the basis of using methods of office research, sociological survey, modeling on the basis of fuzzy logic with the use of expert assessments. The leading role of the factor of internal influence, which covers human values that can be improved by raising the educational and cultural level of the population, which is undoubtedly related to income is proved.
\end{abstract}

\section{Introduction}

In today's conditions, when there is a growing need to reduce the ecological footprint of human activity, the transition from consumption approaches to the principles of sustainable development, the task of ensuring consumption safety is relevant. At the current stage of the global economy development, it is important to alleviate the relationship between socioeconomic growth and environmental degradation due to the internationalization of production and goods and services consumption, which in Ukraine, according to the UN Development Program, reaches $75 \%$ of total environmental impact and $60 \%$ consumer spending [1]. Problems of unsatisfactory health, obesity, diseases are caused by environmental conditions and unreasonable consumption. And these problems require solutions at all levels of the systemic hierarchy of management (global, megaregional, national, regional, of economic entities and end users) and that also depends on all stakeholders interests harmonization. Though there is the primacy of a man as an object of national interests protection, at the same time an individual as the end consumer is relative insecure in economic processes (due to lack of education, institutional imperfection, aggressive communications, etc. Thus it is important to create conditions for conscious, reasonable, sustainable, environmental choices with long-term consequences, here we mean focus on safety of consumption. In a broad sense, the consumption safety

\footnotetext{
* Corresponding author: ekaterinaia@ukr.net.
}

is interpreted as the ability of the state, society and business to create the preconditions for the conscious satisfaction of human needs for self-reproduction to protect the health of the nation and the environment as imperatives for future development. Ensuring consumption as a basis for sustainable consumption concept implementing and sustainable development providing to solving global problems of waste, irrational nature management, excessive consumption. The conceptual principle of sustainable consumption is the formation of rational consumer habits not only in saving money, but also in maintaining health, saving resources and limiting the negative impact on the environment, which remains an important component of quality and safety of human life. That is, within the outlined issues, it is necessary to take into account the factors of internal and external influence on the consumer behavior ecologization, which in today's conditions mostly have a negative context and need to change with a focus on long-term results.

\section{Literature review}

Summarizing the results of research in developed countries [2] suggests that scientists pay considerable attention to the problematic aspects of sustainable consumption, analysis of demand, perception, consumer behavior patterns, lifestyles, consumption culture, corporate social responsibility, brand ethics, storage and disposal, etc. There is a sufficient prevalence in developed countries of sustainable 
aspects of consumption (Table 1), although a significant role is given to the state and scientific and technological progress. Instead, domestic consumers, also hoping for a political and technological solution, are characterized by a less progressive attitude to the environment and, consequently, to sustainable development (which can be explained by the low solvency of a large part of the population), although they try to take steps to change lifestyles in this direction.

Table 1. Attitudes of consumers to environmental protection, $\%$ of respondents.

\begin{tabular}{|c|c|c|c|c|c|c|c|c|c|c|c|c|}
\hline & 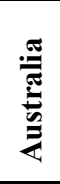 & 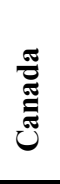 & $\stackrel{\mathscr{B}}{\circlearrowright}$ & 异 & 馬 & 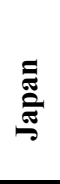 & $\underset{\mathscr{J}}{\mathscr{D}}$ & 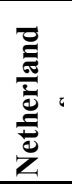 & $\begin{array}{l}\text { 荎 } \\
\text { के }\end{array}$ & 总 & 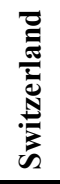 & \\
\hline $\begin{array}{l}\text { Transferring the solution of the problem to future } \\
\text { generations }\end{array}$ & 19 & 18 & 17 & 20 & 8 & 24 & 13 & 18 & 22 & 12 & 11 & 23 \\
\hline $\begin{array}{l}\text { Willingness to accept the environmental decisions with } \\
\text { regard to others }\end{array}$ & 18 & 17 & 7 & 36 & 10 & 27 & 27 & 29 & 13 & 23 & 26 & 5 \\
\hline Underestimation of environmental consequences & 46 & 38 & 20 & 35 & 23 & 47 & 38 & 42 & 39 & 37 & 38 & 10 \\
\hline $\begin{array}{l}\text { Belief in solving environmental problems through the } \\
\text { technological process }\end{array}$ & 35 & 35 & 38 & 28 & 21 & 49 & 51 & 53 & 46 & 26 & 34 & 21 \\
\hline $\begin{array}{l}\text { Unwillingness to pay their own money to solve } \\
\text { environmental problems }\end{array}$ & 72 & 68 & 61 & 67 & 72 & 58 & 64 & 54 & 78 & 60 & 60 & 22 \\
\hline $\begin{array}{l}\text { Willingness to change the way of life in favor of the } \\
\text { environment }\end{array}$ & 79 & 86 & 93 & 87 & 87 & 56 & 98 & 78 & 91 & 81 & 87 & 50 \\
\hline
\end{tabular}

Source $[2,3]$

Prevention of environmental degradation, rejection of those types of goods and services that significantly worsen the environmental situation can be provided due by development of the consumption culture, which G. Shambrovsky understands as a socio-psychological characteristic, individual manner, peculiarities of human behavior in the process of consumption and use of material and spiritual property, and also beliefs about the usefulness of performance results. It is formed under the influence of internal and external psychological, social and economic factors. And the basis for its development is formed by cultural values, which are a set of social norms, rules, standards, that most people follow and which perform a regulatory function for their behavior [4]. Values are consideration mandatory in the marketing system, because the goods, services and social ideas that contradict them are perceived by people as hostile. However, in conditions of acute socio-economic crises cultural values can change significantly [5]. Among the obstacles to strengthening consumption safety in Ukraine the main are the lack of appropriate values, existing habits, as well as insufficient protection of consumer rights by the state and the presence of dangerous goods.

Correlated with national values is the fact that domestic consumers are primarily concerned about caring for the environment $(35 \%)$, respect for human rights $(32 \%)$ and support for domestic producers (31\%). At the same time, we consider it unfavorable that none of these principles worries the majority of consumers, and $18 \%$ of respondents did not even thought about them.

According to the results of the author's research [3], the most important motive for choosing products is health safety, and this condition is the most important in terms of quality of goods and services (especially the quality of food, which, according to surveys $[6 ; 7$, p. 62]) domestic consumers consider the most pressing problem). This feature was mentioned by $88 \%$ of respondents, as opposed to $33 \%$ of respondents, for whom environmental safety is more important. Also, among the main features of consumption safety, environmental safety gives way to health safety and compliance with standards and norms. This correlates with the conclusion that consumers are primarily inclined to worry about short-term or more significant needs [8].

Sociological surveys of consumers $[8,9]$ show that most respondents consider it necessary to use organic products, but not all use it. The main attention is paid to the degree of usefulness and safety for health, and not to the elimination of negative impact on the environment [10, p. 13].

Along with the inability of a significant part of the population of Ukraine to buy ecological goods mainly due to lack of funds, there is a tendency to reduce the share of consumers willing to pay more for ecological goods. In this regard, there is a certain connection between the data of surveys in 2011 [8, p. 63-68] and 2019 (field author's sociological study [3]). Despite the fact that it is possible to indicate temporal, spatial (different regions of Ukraine), quantitative (sample size) differences, they rather reflect the relevance of the results and the dynamics of change.

Situational factors today are mostly characterized by a negative impact on consumption safety. It is worth noting the imperfection of the institutional basis of consumption safety, in particular the low level of consumer protection. This, along with the low level of development of corporate social responsibility and unsatisfactory socio-economic and environmental status of the country complicates the process of consumer decision-making on the choice of goods (services). Previous events, experiences and mistakes can also be influential in this case. Thus, the majority of respondents $(56 \%)$ sometimes encountered unsafe consumption, and among the cases of misleading unfair 
advertising and promotions, concealment of dangerous ingredients and inaccuracy of information on the packaging were often called.

In the context of corporate social responsibility, it can be argued that Ukrainian consumers primarily consider it in the narrow aspect of consumption safety, they understand it as health care $(88 \%)$, while only $45 \%$ of respondents are concerned about the impact on the environment. Comparison of the obtained results with the results of foreign research indicates a low level of demand of domestic consumers. Accordingly abroad consumers choose social responsibility and image (brand) as the main features for evaluating companies and identify interest in companies efforts to become more responsible [11, 12]).

Based on this, it is worth agreeing with the experts [13] that a true understanding of the social and institutional context of consumer action opens a creative view of innovation processes, the key task of which should be the transition from "reflection" to "development" models. For which it is necessary to determine the main factors influencing the ecologization of consumer choice and justify the direction of action aimed at creating conditions for its provision.

\section{Methods}

To determine the most significant factors influencing consumer behavior in the context of ensuring, including ecologization of consumption, the author a sociological study in the form of a questionnaire based on a simple unique quota sample with quotas by age, income, place of residence, education and gender is conducted.

Based on the analysis of the main factors of influence taking into account the peculiarities of consumption safety (uncertainty, hidden, fuzzy relationships between components, time delay), a model of probability of consumer decision on the choice of goods (services) based on consumption safety has been built [3]. The incompleteness or absence of statistical information on consumption safety parameters does not allow the use of formal models based on certain assumptions. That is why we consider the methods of fuzzy logic as a rational way to predict the behavior of individual consumers, which allows to formalize processes that are uncertain or fuzzy in nature, and to describe the algorithm of consumer behavior and assess its state based on modeling initial (factor) features $[14 ; 15]$.

To describe the input $\left(\mathrm{X}_{1}, \mathrm{X}_{2}, \ldots \mathrm{X}_{\mathrm{n}}\right)$ and output $(\mathrm{Y})$ variables we use linguistic evaluation according to the terms on the basis of which using a tree of logical conclusions (Figure 1) we formulate databases of expert evaluations (by group and individual survey). They are fuzzy carriers of information about available relationships between input and output variables. That is, decisions on the membership function of fuzzy subsets, which describe the consumption safety in conditions of uncertainty, are made at a certain point in time on the basis of factors selected by the expert method.

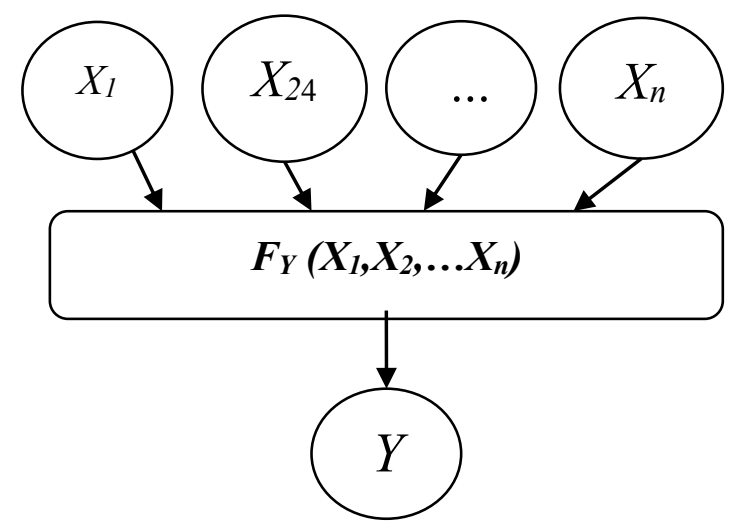

Fig. 1. The relationship between input and output variables of consumer behavior on the basis of consumption safety Source: proposed by the authors

The obtained results are the basis for building a model of safe, including environmental, consumption, which takes into account the positive, neutral or negative impact of external, internal and situational factors at different stages of this process.

\section{Results and discussion}

To identify and counteract threats to consumption safety based on impact factors, we will consider in detail the process of consumption, taking into account the peculiarities of each of its stages: awareness of needs, search for information, evaluation of alternatives, purchasing, use and utilization. The stage of behavior after purchase should be investigated within the sub-stages that differ in needs and functional features: transportation and storage, use, disposal, perception. Note that although the perception may precede some other stages, in this case it is a question of forming a final, generalizing judgment, a conclusion according to which the consumer will plan his further actions. We will also remind you of the importance of feedback, especially at the current stage of development, when e-commerce is gaining in scale, and reviews of goods (services) are one of the main criteria for choosing products.

1. At the stage of awareness of the need the consumer feels dissatisfaction of interest under the influence of various factors. Thus, the real need is usually determined by internal factors, although its expression, in particular according to consumption safety, depends on values, motives, level of education, income and other psychological and individual indicators of previous experience, and lower or higher level of need and timing (present - future).

At the same time, external factors in the conditions of obsessive marketing or the corresponding environment (influence of a social group, subculture) can cause spontaneous needs, which will lead to waste. It is worth agreeing with O. Prokopenko [8] that an important and promising "purchasing power" in terms of consumption safety can be children who significantly influence parents' purchasing decisions and are future consumers and intermediaries between 
producers and parents. In the United States, more than a third of parents have changed their buying behavior because their children have convinced them of the importance of environmental issues. Students who are the most socially active group of the population are also active supporters of environmental organizations. Thus, $26 \%$ of freshmen in US colleges participate in environmental cleansing and conservation programs.

At this stage, the significant influence is made even by such factors of the global environment as political, legal, geopolitical, technological, which determine: confidence in the future, market demand (solvency, demanding, propensity to consume) and supply (innovation, safety, price, etc.).

The threat to the consumption safety is the ability (skills) to formulate correctly the need (taking into account the consequences for health, environment, society, self-development), to hypothesize the choice criteria (quality, naturalness, social responsibility of contractors (manufacturers, intermediaries) etc.), the required amount, etc.

A combination of rational and emotional motives is theoretically desirable. It should be borne in mind that the concepts and, consequently, the characteristics of the safety of goods (services) are narrower to the safety of consumption, and safety requirements may differ for goods (services). In addition, behaviors in which the usual choice criteria do not take into account the safety can be threatening. It is worth agreeing with the opinion [13] that determining the exact correlation of affective, moral, habitual and social motivations and situational conditions is not an easy task.

Various events and situations, such as emergencies, which increase the motivation of safety-oriented consumption, as well as accidental and predictable situations of interaction between consumers and products (primarily merchandising), which encourage a decrease or increase in safety-oriented consumption can be considered as situational factors influencing the safety of consumption [2].

The moderating effect of external situational factors on consumer intentions emphasizes the need to improve and alleviate conditions in a wide range of environmentally important situations. And, perhaps most notably, the integration of the individual into a social group indicates the vital influence of social and cultural context on consumer behavior.

Consumption culture determines the safety of consumption in stages of:

- awareness - affects the definition and formulation of safety requirements;

- search - influences the choice of information sources according to their reliability evaluation;

- choice - affects the definition of essential features and criteria;

- use - affects consumption without endangering health and the environment during transportation, storage, use and disposal.

The influence of the culture of consumption in the process of feedback in the conditions of satisfactory, and especially unsatisfactory experience of consumption (use) of the goods (service) is important.
2. At the stage of information search such threats as its completeness, reliability, accessibility, may be affected by: information search skills, level of awareness and education of the consumer, experience gained in previous use, perception; aggressiveness of the supply (level of competition, competitiveness, obsession of communications: frequency, channels, content of messages, etc.); institutional environment (regulatory mechanisms, protection tools), in particular information security, development of information and communication technologies; reference groups, their values, experience, feedback as a source of information about goods (services).

If the product (service) belongs to the category of daily demand, which is characterized by a model of normal behavior and choice, consumer orientation and situational factors (availability at the point of sale, means of sales promotion on the ground) are important. T. Jackson considers the need to understand and study the possibility of influencing the formation and change of habits in consumer actions the key factors for further study and promote behavior change that shape and constrain consumer choice [13].

O. Prokopenko notes that the bulk of consumers in the case of new product appearance on the market first gets acquainted with composition product with the information provided on the package, evaluates the environmental friendliness of the product [8]. In the future, consumers only compare the price of the product with the idea of environmental friendliness and so on. At the same time, middle-income people focus on environmental friendliness and taste characteristics of products.

In addition, the "cognitive trap" is reflected in routine behavior, even when it contradicts rational considerations and social norms and causes changes in best intentions. As stated in the report "Motivation for Sustainable Consumption" "... even if we can persuade people to change their views and beliefs in favor of actions to protect the environment, even if we can convince them of the need to behave prosocially through prohibitive or descriptive social norms, even if we can get people to adopt personal environmental standards, there is still no guarantee that they will behave accordingly in the world around them" [13]. Thus, behavioral change to protect the environment and ensure the safety of consumption is a daunting task.

3-4. In the context of consumption safety, the stages of evaluating alternatives and making a purchase decision can be considered together, as the consumer is influenced by the following factors:

- internal - values, motives, income level;

- external - marketing; advertising, in particular at points of sale, packaging; price; socio-cultural, reference groups;

- situational - availability, conditions, advice of the consultant, promotions.

In our opinion, the greatest threat at these stages is the unreasonable choice of criteria for comparing and evaluating goods (services) (emotional, affective; due to the environment, obsession).

At these stages, the threat may be: 
- lack of skills, lack of necessary information, complexity of conditions (limited time, space) for evaluating criteria;

- use first of all of compensatory assessment models where non-compensatory ones should be used: for hazardous components, doubts about shelf life, etc;

- disregard for tangible and intangible costs for storage, disposal after the purchase of goods (services).

5. Regarding consumer behavior after purchase, in particular in our country, it is advisable to pay attention to safety issues at the stage of direct use and disposal. This is due to greater regulation and institutional protection of the processes of purchase, transportation and storage of products (goods), which are more responsibly followed by most consumers. Although the conditions of use and disposal are also clearly defined, the problem of their compliance remains unresolved. Thus, as noted in [16, p. 29], in the future this will be demanded not only by politicians but also by consumers, but at present no country combines a high level of development with sustainable environmental consumption.

Our country is characterized by a situation where a significant part of the population (53\%) does not sort garbage. That is largely due to the lack and imperfection of the relevant infrastructure. While the main reasons for significant volumes of consumption waste, respondents believe that too much packaging $(63 \%)$.

The conditions of our country at the stage of goods (services) using are also threatened by ignorance, ignoring the requirements for storage and disposal, underdeveloped disposal infrastructure, inability of consumers due to lack of knowledge, skills, information, underdeveloped institutional environment to protect their rights and more. The latter can be mitigated by establishing negative feedback.

Dangerous, especially in the long run, is the inability or difficulty to assess the level of satisfaction of the need through imposed means of marketing communications (advertising, personal sales, public relations tools), feeling excessive or insufficient satisfaction when there is a desire to repeat the purchase.

Factors of internal and external influence as values, culture of consumption, marketing (promotion), level of development of institutional base (legislation, social norms) are chosen as input variables of consumers behavior modeling by methods of fuzzy logic (Table 2) evaluated by expert method. Regarding such a factor of external influence as marketing the unevenness of the intervals can be explained by its nature, which is to achieve the main goal - the persuasion of consumers to make a purchase and to be loyal. Thus, most marketing communications have a negative or relatively negative impact on consumption safety. Reports of positive impact are likely to be exceptions at the request of society and the state, or measures within the framework of corporate social responsibility, the imitation of which is more costly and insufficient in

Ukraine. The difference in the intervals for the factors of values and the institutional basis is also due to the imperfect level of their development and non- compliance with the requirements of consumption ensuring. The formation of appropriate consumption habits is a gradual process, as is the indicator by which we assess the safety of consumption.

The conducted modeling of consumption safety depending on the chosen factors of internal and external influence on the basis of methods of fuzzy logic allowed to optimize indicators of consumption safety level (Table 3, Figure 2). To achieve the optimal (not below average) level of consumption safety $(0.4$ and above) it is necessary to fulfill simultaneously the following prerequisites:
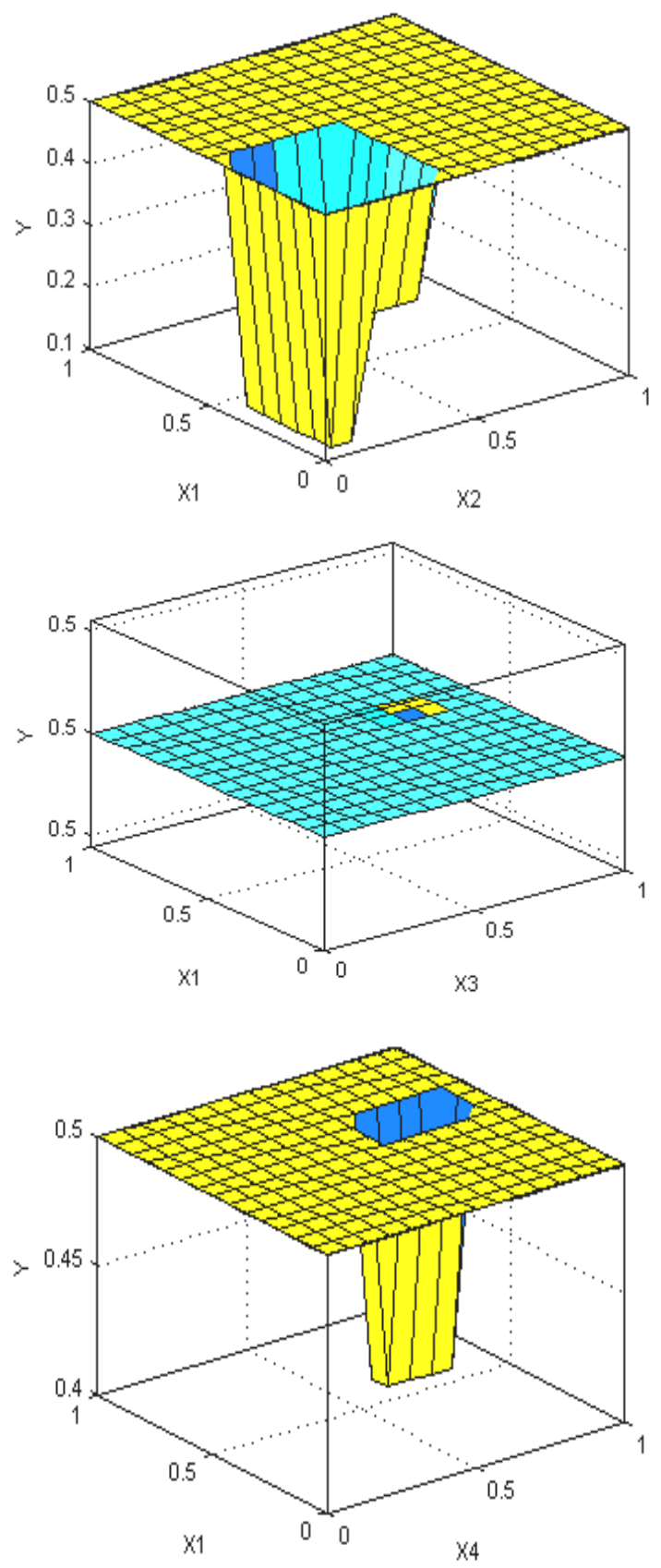

Fig. 2. Dependence of consumption safety level on indicators of internal and external influence, which include human values $\left(X_{1}\right)$, consumption culture $\left(X_{2}\right)$, marketing (promotion) $\left(X_{3}\right)$ and the state of the institutional base in the country $\left(X_{4}\right)$ Source: built by the authors 
Table 2. Linguistic evaluation and interpretation of variables in the process of modeling consumer behavior on the basis of consumption safety by fuzzy logic

\begin{tabular}{|c|c|c|c|c|c|c|}
\hline \multirow{2}{*}{$\begin{array}{l}\text { Par } \\
\text { ame } \\
\text { ters }\end{array}$} & \multirow[b]{2}{*}{ Type } & \multicolumn{5}{|c|}{ Terms } \\
\hline & & Very low & Low & Average & High & Very high \\
\hline \multirow[t]{2}{*}{$\mathrm{X}_{1}$} & \multirow[t]{2}{*}{ Values } & $\begin{array}{l}\text { Negative for } \\
\text { consumption safety } \\
\text { (survival values, } \\
\text { overconsumption, } \\
\text { distrust to } \\
\text { institutions) }\end{array}$ & $\begin{array}{l}\text { Negative (the } \\
\text { presence of one } \\
\text { or more signs of } \\
\text { negative values) }\end{array}$ & $\begin{array}{l}\text { Neutral: } \\
\text { in certain areas } \\
\text { (product safety, health } \\
\text { care, family - } \\
\text { egocentric) or not } \\
\text { always }\end{array}$ & $\begin{array}{l}\text { Relatively } \\
\text { positive: } \\
\text { following of a } \\
\text { significant } \\
\text { number of } \\
\text { positive values }\end{array}$ & $\begin{array}{l}\text { Positive: } \\
\text { values of self- } \\
\text { development, care } \\
\text { for the environment, } \\
\text { well-being of future } \\
\text { generations }\end{array}$ \\
\hline & & $\mathrm{X}_{1}=0-0.25$ & $X_{1}=0,26-0.5$ & $\mathrm{X}_{1}=0.51-0.7$ & $\mathrm{X}_{1}=0.71-0.85$ & $\mathrm{X}_{1}=0.86-1$ \\
\hline \multirow[t]{2}{*}{$\mathrm{X}_{2}$} & \multirow[t]{2}{*}{$\begin{array}{l}\text { Consump- } \\
\text { tion } \\
\text { culture }\end{array}$} & $\begin{array}{l}\text { Low level } \\
\text { (consumpting } \\
\text { everything without } \\
\text { thinking about the } \\
\text { usefulness and } \\
\text { consequences) }\end{array}$ & $\begin{array}{l}\text { Relatively low } \\
\text { level (more } \\
\text { often not think- } \\
\text { ing about the } \\
\text { consequences } \\
\text { for health or the } \\
\text { environment) }\end{array}$ & $\begin{array}{l}\text { Average } \\
\text { (worrying about the } \\
\text { consequences from } \\
\text { time to time) }\end{array}$ & $\begin{array}{l}\text { Relatively high } \\
\text { (providing } \\
\text { several high- } \\
\text { level } \\
\text { conditions) }\end{array}$ & $\begin{array}{l}\text { High level } \\
\text { (balanced approach } \\
\text { to how much, when, } \\
\text { how and what } \\
\text { consumes, care } \\
\text { about the } \\
\text { consequences) }\end{array}$ \\
\hline & & $\mathrm{X}_{2}=0-0.2$ & $\mathrm{X}_{2}=0.21-0.4$ & $\mathrm{X}_{2}=0.41-0.6$ & $\mathrm{X}_{2}=0.61-0.8$ & $\mathrm{X}_{2}=0.81-1$ \\
\hline \multirow[t]{2}{*}{$\mathrm{X}_{3}$} & \multirow[t]{2}{*}{$\begin{array}{l}\text { Marketing } \\
\text { (promo- } \\
\text { tion) }\end{array}$} & $\begin{array}{l}\text { Negative impact } \\
\text { (presence of a } \\
\text { significant amount of } \\
\text { deceptive, intrusive, } \\
\text { aggressive } \\
\text { advertising, deceptive } \\
\text { packaging, } \\
\text { promotions, PR) }\end{array}$ & $\begin{array}{l}\text { Relatively nega- } \\
\text { tive impact (a } \\
\text { significant } \\
\text { number of } \\
\text { negative marke- } \\
\text { ting factors, } \\
\text { sometimes - an } \\
\text { informative } \\
\text { component) } \\
\end{array}$ & $\begin{array}{l}\text { Neutral influence } \\
\text { (informative and } \\
\text { information nature of } \\
\text { advertising and other } \\
\text { communication } \\
\text { activities about the } \\
\text { product or service) }\end{array}$ & $\begin{array}{l}\text { Relatively } \\
\text { positive impact } \\
\text { (mostly infor- } \\
\text { mative comer- } \\
\text { cial advertising, } \\
\text { sometimes - } \\
\text { popularization } \\
\text { of sustainable } \\
\text { development } \\
\text { principles) } \\
\end{array}$ & $\begin{array}{l}\text { Positive impact } \\
\text { (mostly social } \\
\text { advertising, } \\
\text { promotion of } \\
\text { sustainable } \\
\text { development } \\
\text { principles and } \\
\text { informative } \\
\text { commercial } \\
\text { advertising) } \\
\end{array}$ \\
\hline & & $\mathrm{X}_{3}=0-0.3$ & $\mathrm{X}_{3}=0.31-0.6$ & $\mathrm{X}_{3}=0.61-0.8$ & $\mathrm{X}_{3}=0.81-0.9$ & $\mathrm{X}_{3}=0.91-1$ \\
\hline \multirow[t]{2}{*}{$\mathrm{X}_{4}$} & \multirow[t]{2}{*}{$\begin{array}{l}\text { Institu- } \\
\text { tional } \\
\text { environ- } \\
\text { ment } \\
\text { (legisla- } \\
\text { tion, } \\
\text { social } \\
\text { norms) }\end{array}$} & $\begin{array}{l}\text { Undeveloped } \\
\text { (legislative and social } \\
\text { norms of } \\
\text { consumption are not } \\
\text { carefully developed } \\
\text { and vaguely } \\
\text { formulated, there are } \\
\text { no behavior ranks for } \\
\text { the consumer) }\end{array}$ & $\begin{array}{l}\text { Relatively } \\
\text { underdeveloped } \\
\text { (most } \\
\text { conditions for } \\
\text { the base } \\
\text { development are } \\
\text { not met) }\end{array}$ & $\begin{array}{l}\text { Partially developed } \\
\text { (consumer does not } \\
\text { follow or partially } \\
\text { follows) legislative } \\
\text { and (or) social norms } \\
\text { of consumption, or } \\
\text { they are not } \\
\text { thoughtfully } \\
\text { developed and not } \\
\text { clearly formulated) }\end{array}$ & $\begin{array}{l}\text { Relatively } \\
\text { developed } \\
\text { (providing most } \\
\text { of the } \\
\text { conditions of } \\
\text { development) }\end{array}$ & $\begin{array}{l}\text { Developed } \\
\text { (consumer follows } \\
\text { legislative and } \\
\text { social norms of } \\
\text { consumption, which } \\
\text { are carefully } \\
\text { designed and clearly } \\
\text { formulated) }\end{array}$ \\
\hline & & $\mathrm{X}_{4}=0-0.3$ & $\mathrm{X}_{4}=0.31-0.6$ & $X_{4}=0.61-0.9$ & $\mathrm{X}_{4}=0.91-0.95$ & $\mathrm{X}_{4}=0.95-1$ \\
\hline \multirow{2}{*}{ Y } & \multirow{2}{*}{$\begin{array}{l}\text { Level of } \\
\text { consumpti } \\
\text { on safety }\end{array}$} & Lower limit & Below average & Average & Above average & High \\
\hline & & $\mathrm{Y}=0-0.2$ & $\mathrm{Y}=0.21-0.4$ & $\mathrm{Y}=0.41-0.6$ & $\mathrm{Y}=0.61-0.8$ & $\mathrm{Y}=0.81-1$ \\
\hline
\end{tabular}

Source: authors' calculations.

Table 3. Perspective marks to ensure the optimal level of consumption safety

\begin{tabular}{|c|c|c|c|c|}
\hline $\begin{array}{c}\text { The value of the } \\
\text { indicator of internal } \\
\text { influence on the basis } \\
\text { of human values, } \\
X_{1}\end{array}$ & $\begin{array}{l}\text { The value of the indicator } \\
\text { of external influence, } \\
\text { which covers the culture } \\
\text { of consumption, } X_{2}\end{array}$ & $\begin{array}{l}\text { The value of the external } \\
\text { influence indicator, which } \\
\text { covers marketing } \\
\text { (promotion), } X_{3}\end{array}$ & $\begin{array}{l}\text { The value of the } \\
\text { indicator of external } \\
\text { influence, which } \\
\text { covers the state of the } \\
\text { institutional base, } X_{4}\end{array}$ & $\begin{array}{c}\text { Level of } \\
\text { consumption } \\
\text { safety, } \\
Y\end{array}$ \\
\hline 0,598 & 0,845 & 0,902 & 0,931 & 0,5 \\
\hline 0,114 & 0,315 & 0,477 & 0,469 & 0,3 \\
\hline 0,386 & 0,315 & 0,447 & 0,469 & 0,2 \\
\hline 0,386 & 0,1 & 0,705 & 0,777 & 0,3 \\
\hline 0,144 & 0,0846 & 0,174 & 0,454 & 0,2 \\
\hline 0,144 & 0,0846 & 0,174 & 0,777 & 0,1 \\
\hline 0,144 & 0,0846 & 0,492 & 0,177 & 0,2 \\
\hline 0,144 & 0,315 & 0,492 & 0,177 & 0,1 \\
\hline 0,402 & 0,315 & 0,492 & 0,177 & 0,3 \\
\hline 0,129 & 0,315 & 0,462 & 0,469 & 0,3 \\
\hline
\end{tabular}

Source: authors' calculations. 
- in the presence of negative for consumption safety values $\left(X_{I} \geq 0.114\right)$ a safe level of consumption can be ensured only if the value of consumption culture is $X_{2} \geq 0.315$, the marketing impact is neutral $\left(X_{3} \geq 0.477\right)$ and institutional base is undeveloped $\left(X_{4} \geq 0.469\right)$;

- for a low level of consumption culture $\left(X_{2} \geq 0.1\right)$ to ensure the consumption safety at level is possible by providing the value of the indicator, which covers human values $X_{1} \geq 0.386$, neutral influence of marketing $\left(X_{3} \geq 0.705\right)$ and the average level of institutional development $X_{4} \geq 0.777$ );

- the value of the indicator of external influence, which covers marketing (promotion) $\left(X_{3}\right)$ should not be lower than 0.462 , which corresponds to the range of relatively negative influence, ie the use by providers of a significant number of marketing factors of negative influence, and sometimes informative component;

- for a very low level of development of the institutional base $\left(X_{4} \geq 0.177\right)$ a safe level of consumption can be provided when the value of the human values indicator $X_{1} \geq 0.402$, there is a relatively low level of consumption culture $\left(X_{2} \geq 0.315\right)$ and relatively negative marketing impact $\left(X_{3} \geq 0.492\right)$.

To achieve a high level of consumption safety, it is necessary to ensure certain levels of indicators of internal and external influence, and in the long run it is necessary to strengthen the factor of internal influence, which covers human values. This problem can be solved by raising the educational and cultural level of the population, which is undoubtedly related to income.

\section{Conclusion}

Consumer behavior reflects changes in demand for different types of goods and the level of welfare of the population, which must be taken into account when determining strategic priorities and modernizing mechanisms for regulating consumer market development, substantiation of state policy to protect consumer rights and promoting the consumer market commodity saturation of with quality domestic products.

The study of consumer behavior in the context of consumption safety ensuring identified the main factors of influence at all stages of purchasing decisions. They include the level of consumption culture, consumer habits, marketing and institutional basis, the composition of which determines the overall level of consumption safety. Achieving a high level of consumption safety is possible by providing defined on the basis of fuzzy logic levels of internal and external influence indicators. In the long run this requires an improvement in the internal impact indicator, which includes human values, through an increase in the educational and cultural level of the population, which is undoubtedly related to income. Thus, further research is needed to develop measures to improve the decision-making environment for safe, including green/ecological consumption, as well as the implementation of educational activities to form values and culture of environmental consumption.

\section{References}

1. Global Environment Outlook-5. UNEP. URL: http://web.unep.org/geo/resources/publications (22.08.2019).

2. N. Johnstone, Y. Serret, Greening Household Behaviour. Main Results of OECD Survey. URL: http://www.sviva.gov.il/English/env_topics/InternationalCooperation/OnTheIntlFront/Documents/ GreeningHouseholdsBehavior-OECDSur veyResults-Nov2013.pdf(15.11.2019)

3. K. I. Antoniuk, Ensuring consumption safety in Ukraine in the process of European integration: theoretical and methodological foundations and applied aspects (NISS, 2020)

4. G. Shamborovsky, Welfare of the population of international integration associations: strategies for Ukraine (Ivan Franko Lviv National University, 2018)

5. The use of consumer psychology in modern marketing. URL: http://osvita.ua/vnz/ reports / psychology/10117/ (15.11.2019)

6. A. V. Rashchenko, Features of the formation of demand for agricultural products in the context of attitude, Agrosvit, 22 (2012)

7. N. V. Zinovchuk, A. V. Rashchenko, Ecological marketing (ZhSU Publishing House. I. Franko, 2015)

8. O. V. Prokopenko, Ecological marketing (Znannya, 2012)

9. A. Izvekov, Marketing research of the fruit and vegetable market and its development, Marketing, $50(2020)$

10. R. A. Perelet, Ya. P. Molchanova, E. V. Pashkov and others, Environmental certification and ecolabeling: the final technical report on the project "Harmonization of environmental standards (HPP II) - Russia”, URL: http://air-q-gov.baes.by/user files/file/air_q_RU/CD/chapter_4/4-2/4-2-10.pdf (14.03.2018)

11. Responsabilidade Social das Empresas - Percepcao do Consumidor Brasileiro (Pesquisa, Instituto Ethos). URL: https:/www.ethos.org.br/wp-content/uploads/ 2012/12/5Pesquisa-2001.pdf (18.11.2019)

12. The Millenium Poll on Corporate Social Responsibility. Global Public Opinion on the Changing Role of Companies. Environics International Ltda, 2000. URL: https://globescan. com/wp-content/uploads/2018/01/GlobeScan MillenniumPoll_1999_FullReport.pdf(18.11.2019)

13. T. Jackson, Motivating Sustainable Consumption -a review of evidence on consumer behaviour and behavioural change (University of Surrey, 2005)

14. A. Kofman, Introduction to the theory of fuzzy sets (Radio and communications, 1982)

15. M. S. Syavavko, O. M. Rybytska, Mathematical modeling under conditions of uncertainty (Ukrainian Technologies, 2000)

16. Consumption:Stakeholder Perspectives A Collection of Personal Essays by World Economic Forum Members and Constituents involved in the Forum's Sustainable Consumption Initiative 2008-2012 and associated Global Agenda Council on Sustainable 
Consumption. (World Economic Forum, Geneva,

Switzerland, 2013). URL: http://www3.weforum.

org/docs/WEF_ENV_SustainableConsumption_Boo

k_2013.pdf(18.16.2017). 